\title{
Protein expression of VEGF, IGF-1 and FGF in retroocular connective tissues and clinical correlation in Graves' ophthalmopathy
}

\author{
Expressão protéica de VEGF, IGF-1 e FGF no tecido conjuntivo retro-ocular \\ e correlação clínica na oftalmopatia de Graves
}

\author{
Kimble Matos ${ }^{1}$ \\ Paulo Gois Manso ${ }^{2}$ \\ Eduardo Marback ${ }^{3}$ \\ Reinaldo Furlanetto ${ }^{4}$ \\ Gustave Nosé Alberti ${ }^{5}$ \\ Vania Nosé ${ }^{6}$
}

Trabalho realizado no Departamento de Oftalmologia da Universidade Federal de São Paulo - UNIFESP - São Paulo (SP) - Brazil.

${ }^{1}$ Department of Ophtalmology, Universidade Federal de São Paulo - UNIFESP - São Paulo (SP) - Brazil.

${ }^{2}$ Department of Ophtalmology - UNIFESP - São Paulo (SP) - Brazil.

${ }^{3}$ Department of Ophtalmology - UNIFESP - São Paulo (SP) - Brazil. Universidade Federal da Bahia - Salvador (BA) - Brazil.

${ }^{4}$ Department of Endocrinology - UNIFESP - São Paulo (SP) - Brazil.

${ }^{5}$ Tufts University Medical Center, Boston, Massachusetts - USA.

${ }^{6}$ Department of Pathology - UNIFESP - São Paulo (SP) - Brazil, and Department of Pathology, Brigham and Women's Hospital, Boston - Massachusetts - USA.

Corresponding author: Kimble Matos. Rua Pintassilgo, 480/135 - Moema - São Paulo (SP) ZIP 04514-032 E-mail: kimblematos@hotmail.com

Work supported by Grant from FAPESP, 98/06350-1 (Fundacão de Pesquisa do Estado de S. Paulo, Brazil)

Recebido para publicação em 27.06.2007

Aprovação em 18.05.2008

\begin{tabular}{l} 
ABSTRACT \\
\hline Purpose: To investigate the immunohistochemical expression (IGF-1, \\
EGFr, EGF, c-erbB-2/HER-2/neu, PDGF-A, PDGF-B, FGF and VEGF) in \\
patients with Graves' ophthalmopathy. Methods: Twenty-four samples \\
(Graves' ophthalmopathy patients) underwent lateral rectus muscle and \\
surrounding fibrous and adipose tissue biopsy. The control group was \\
obtained by strabismus surgery. Correlation between clinical- ophthalmo- \\
logic, endocrinological, ultrasonographic findings, and immunohistoche- \\
mical expression was performed. Results: IGF-1: There were 7 positive \\
cases (29.2\%). There was a directrelation with higher CAS (clinical activity \\
score) in all of them and if only CAS equal or higher than 5 was considered, \\
this was 54.5\%. FGF: There was expression in 5 cases (20.8\%) with a direct \\
relation in all those with higher CAS (>5) (45.4\%). VEGF: There were two \\
positive cases (8.3\%) for VEGF in endothelial cells, in these cases the \\
patients also presented CAS higher than 5. There was no expressions of \\
all growth factors in the control group. Conclusions: All patients, except \\
one, with positive expression of FGF, IGF-1 and VEGF showed CAS \\
greater than 5, suggesting in this way an important role of these growth \\
factors in the pathogenesis and severity of Graves' ophthalmopathy. Ho- \\
wever, statistical analysis revealed only significant association between \\
IGF-1 and male sex (P=0.034). Low ultrasound reflectivity and endocrine \\
status may not correlate directly with disease activity or with immuno- \\
expression of growth factors and c-erbB-2/HER-2/neu.
\end{tabular}

Keywords: Imunohistochemstry; Receptor, erbB-2/analysis; Insulin-like growth factor I/analysis; Receptor, epidermal growth factor/analysis; Epidermal growth factor/analysis; Platelet-derived growth factor alpha/analysis; Proto-oncogene proteins c-sis/analysis; Fibroblast growth factors/ analysis; Vascular endothelial growth factor A/analysis; Graves' ophthalmopathy/metabolism

\section{INTRODUCTION}

Thyroid associated ophthalmopathy (TAO) is a potentially severe disease.

Ophthalmopathy, the most frequent extra-thyroidal manifestation of Graves' disease, results from an increased volume of the orbital tissues ${ }^{(1)}$. Orbital T cells, fibroblasts, adipocytes and perhaps other residential cells would release numerous cytokines, growth factors and inflammatory mediators, many of which act as potent stimulators of glycosaminoglycan accumulation and edema formation ${ }^{(2)}$.

The pituitary gland is rich in $\mathrm{FGF}^{(3)}$ and $\mathrm{IGF}^{-1}{ }^{(4)}$, and these growth factors are well known to stimulate fibroblast proliferation and secretion of 
collagen and glycosaminoglicans. It is interesting that patients with ophthalmopathy present in their extraocular muscles more IGF-1 receptors ${ }^{(5)}$.

We attempted to investigate the immunohistochemical expression of c-erbB-2/HER-2-neu, IGF-1 (Insulin-like Growth factor-1), EGFr (Epidermal Growth Factor receptor), EGF (Epidermal Growth Factor), PDGF-A (Platelet-derived Growth Factor-A), PDGF-B (Platelet-derived Growth Factor-B), FGF (Fibroblast Growth Factor) and VEGF (Vascular Endothelial Growth Factor) in retroocular connective tissue and extraocular muscles in patients with Graves' ophthalmopathy and their clinical correlation.

\section{METHODS}

This was a study of twenty-two sequential patients with Graves' ophthalmopathy, who were referred to the Federal University of São Paulo, São Paulo, Brazil.

Two ophthalmologists evaluated all patients. The clinical activity score (CAS) was used ${ }^{(6)}$. To assess the disease severity, the NOSPECS classification ${ }^{(7)}$ was used.

The diagnosis of Graves' ophthalmopathy was based on the presence of the typical clinical and laboratorial features in combination with enlargement of extraocular eye muscles on ultrasound scan as published by Bartley \& Gorman $^{(8)}$.

Eye muscle diameter and reflectivity was assessed with standardized A- and B-mode ultrasonography of both orbits, using an Ophthscan-S unit (ALCON) with $10 \mathrm{MHz}$ frequency ${ }^{(9)}$. In the A- and B-mode, the sound beam was directed perpendicularly to the axis of the rectus bulbi muscle based on Polaroid pictures taken during the examination. The eye muscle reflectivity was defined as the mean of the distance from the baseline to the top of all spikes within the anterior and posterior muscle sheaths in relation to the sclera spike, which was assumed to be $100 \%$. These results were expressed as high, medium or low reflectivity, using the standard methods described by Prummel et al. ${ }^{(10)}$.

There were 20 patients who had one biopsy, and 2 patients who had both eyes biopsied. In general our choice was based in the worse eye, if there was disease activity. Samples of connective tissue surrounding muscle fibres and lateral rectus muscle from all patients were obtained by the same ophthalmologist, with the patient's informed consent and Institutional Review Board (IRB)/Ethics Committee approval. All biopsies, which measured between 2.2-3.8 mm, were performed using the transconjunctival approach, with tissue taken from the superior portion of lateral rectus muscle and including surrounding tissues. The samples from the control group $(n=4)$ were obtained during routine non-thyroid-related corrective strabismus surgery. Half of the obtained tissue was frozen immediately after surgery at $-70^{\circ} \mathrm{C}$. The other half was kept for 12-24 hours in 10\% buffered formalin, 5 minutes under pressure in a pressure cooker and processed for routine histological sections $^{(1)}$.
For the routine stains, such as hematoxylin and eosin, periodic acid Schiff (PAS), alcian blue, and for the immunohistochemical study, paraffin $4-\mu \mathrm{m}$ thick sections were cut. For immunohistochemistry, the sections were deparaffinized and placed in a methanol with $0.3 \% \mathrm{H}_{2} \mathrm{O}_{2}$ solution for $30 \mathrm{~min}$. Sections were then incubated for $20 \mathrm{~min}$ with the following antibodies: c-erbB-2/HER-2/neu: Polyclonal antibody for rabbit IgG, (1:50 dilution). EGFr: Polyclonal antibody for rabbit IgG, (1:50 dilution). EGF: Polyclonal antibody for rabbit IgG (undiluted). IGF-1: Polyclonal antibody for goat IgG (undiluted). FGF: Polyclonal antibody for rabbit IgG (1:50 dilution). PDGF A e B: Polyclonal antibody for rabbit IgG (1:50 dilution). VEGF: Polyclonal antibody for rabbit IgG (1:50 dilution), all from Santa Cruz Biotechnology Inc., USA.

For detection the streptavidin-biotin complex- Duet mouse/rabbit, Dako Corporation, Santa Barbara, California (K0492/ lot 126), in a dilution of 1:800 was used.

After washings with $0.01 \mathrm{mM}, \mathrm{pH} 7.4$ phosphate-buffered saline (PBS), sections were counterstained with hematoxylin, dehydrated and mounted.

We assessed associations between variables using Spearman's rank correlation coefficient for continuous variables and Fisher's exact test for categorical variables.

\section{RESULTS}

The study group consisted of 22 patients, with 24 biopsy specimens, which fulfilled the inclusion criteria. As a complication of the biopsy only two patients presented mild pain after the procedure, which disappeared in two days with oral NSAID. The control group consisted of 3 patients, with 4 biopsies (one of whom was subjected twice to strabismus surgery). There were 10 males and 12 females in Graves' group and 3 females in a control group. The age range was 21 to 58 years, the average being 41 years. In terms of drug usage, 8 patients were on thiamazol, 5 were taking propranolol, 3 patients prednisolone, 2 L-tiroxin sodium salt, 2 colchicine, 1 diclofenac sodium, and 1 was on propylthiouracyl. Time of biopsy from onset of ocular disease ranged from 1 month to 84 months, with an average of 20.6 months. With regard to the endocrinological status, 16 patients were euthyroid, 7 patients presented with hyperthyroidism, and 1 patient presented with hypothyroidism.

The echography results disclosed an enlargement in all extraocular recti muscles except one, following the patterns found by Byrne et al. ${ }^{(11)}$.

Our immunohistochemistry findings for c-erbB-2 (HER2neu), EGFr, EGF, IGF-1, FGF, PDGF-A, PDGF-B and VEGF were:

C-erb-2- immune reaction was considered non-specific in the cytoplasm of neutrophils, and around vessels in 4 cases (16.7\%), and negative in all the rest. If we considered only CAS equal or higher than 5 then $27.3 \%$ were non-specific. There were no specific immune stains for fibrous tissue, fibroblasts or muscle tissue.

EGF-r (Epidermal Growth Factor-receptor): There was no immunoreactivity in all biopsied samples. 
EGF (Epidermal Growth Factor): There was immunoreactivity in two cases $(8.3 \%)$, non-specific in neutrophils. There was no reaction in muscular fibrous tissue.

IGF-1 (Insulin-like Growth Factor-1): Seven cases were positive $(29.2 \%)$. The immunoreactivity was mainly in the connective tissue and fibroblasts (Figure 1A). We could not demonstrate this reaction in muscle fibres and fat tissue (in these tissues, the reaction was mild and considered non-specific).

In the 7 cases of positive IGF-1, there was a correlation with greater CAS (at least 5) in the cases 3a, 3b (Figure 1A), $6,7,12$ and $21,(54.5 \%)$ with exception of case 13 . Nevertheless, there was a patient with CAS 10 and negative IGF-1.

FGF (Fibroblast Growth Factor): There was positive expression in 5 cases (patients 3a and 3b, 6, 12 and 22) (20.8\%) in 24, and there was a direct relation between positivity and higher CAS in all of these. If we considered only patients with CAS equal or higher than 5 , then $45.4 \%$ were positive. The immunoreactivity was located in the cytoplasm of fibroblasts and connective tissue (Figures 1A, B and C).

PDGF-A and PDGF-B (Platelet Derivate Growth Factor): There was no expression of alpha and beta-PDGF. In two cases (16 and 20), there was a non-specific stain in amorphous tissue.

VEGF (Vascular Endothelial Growth Factor): There were two cases (7 and 12) (8.3\%) with immunoreactions for VEGF in endothelial cells; in these cases the patients also presented CAS higher than 5 (Figure 1D). All these data are summarized in table 1, and the relevant numbers of samples and IGF-1, FGF and VEGF expression in table 2.

In the control group, which consisted of 4 samples, there was no expression of any growth factor and c-erbB-2.

Our statistical analysis revealed evidence of as association between IGF-1 and sex ( $\mathrm{P}=0.034$, Fisher's exact test) (Graph 1). We found no evidence of any association between the other variables under study, however it is important to realize that the number of patients in the study is small and thus the power to detect significant differences is low.

\section{DISCUSSION}

There may be less difference between the six extraocular muscles in their pathological involvement than is clinically

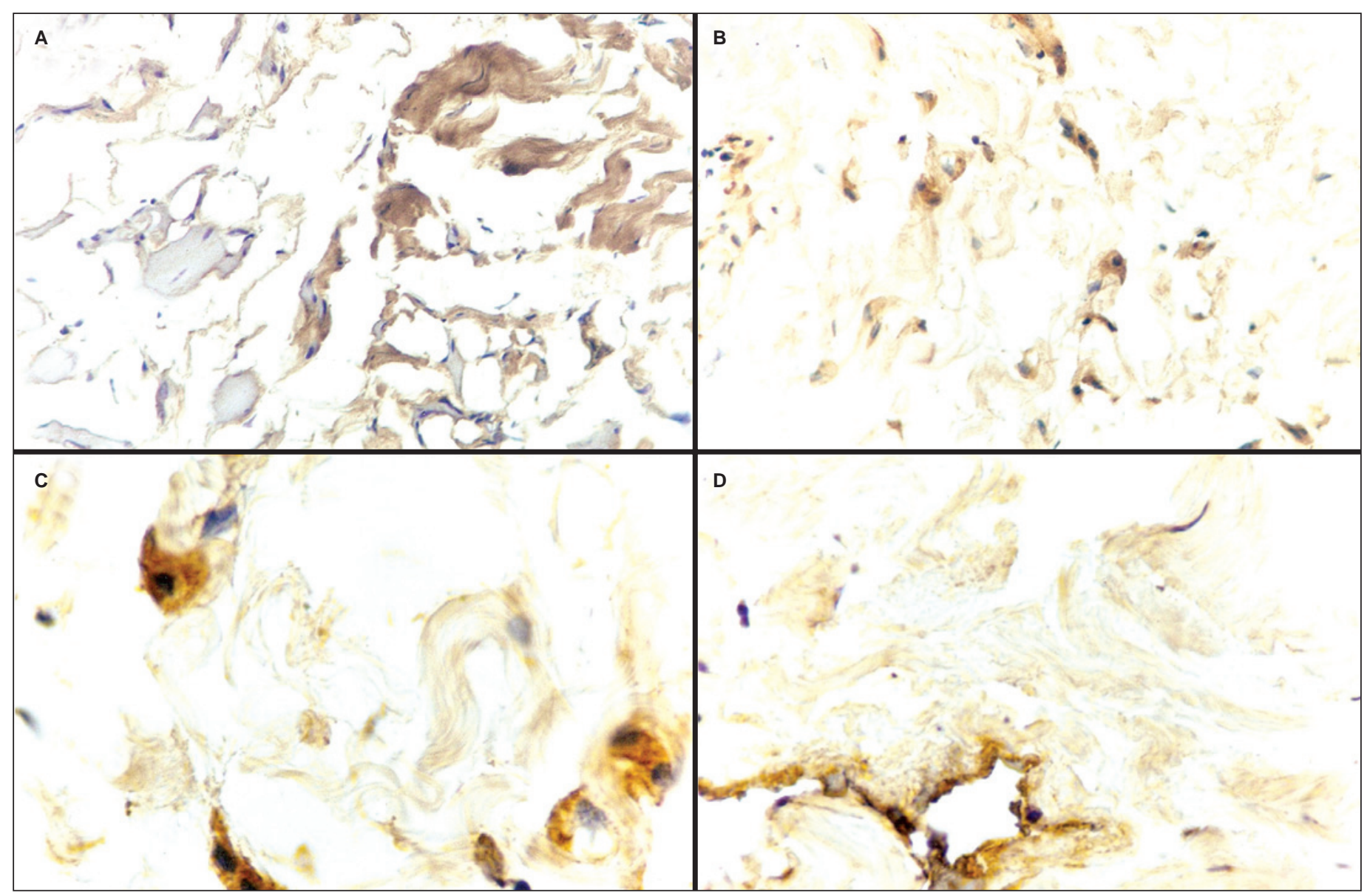

Figure 1 - (A) IGF-1 positive immunoexpression in connective tissue. Muscle fibers IGF-1 immunoexpression negative. (40X). (B) Connective tissue. FGF immunostaining severe immunoreaction at cytoplasmic level in fibroblasts and diffusely in connective tissue. (400X). (C) Connective tissue. FGF immunoexpression in fibroblasts, cytoplasmic level, granular shape. (1000X). (D) VEGF immunostainning. VEGF immunoexpression in endothelial cells in a vessel. Unespecific staining in connective tissue . (400X). 


\begin{tabular}{|c|c|c|c|c|c|c|c|}
\hline Patient & Sex & Age & Medication radiotherapy & CAS & Endocrinology & Ultrasound & Immunohistochemistry \\
\hline 1 & $\mathrm{M}$ & 41 & $\mathrm{~T} 5 \mathrm{mg}$ & 6 & $E$ & $\mathrm{R}=4.5 \mathrm{Me}$ & c-erbB-2 + Neutrophils \\
\hline 2 & $\mathrm{~F}$ & 58 & $\mathrm{~T} 30 \mathrm{mg}$ & 1 & $\mathrm{He}$ & $\mathrm{R}=8.4 \mathrm{Me}$ & Negative \\
\hline $3 a$ & M & 33 & $\begin{array}{c}\operatorname{Pr} 10 \mathrm{mg} \\
\text { C } 1 \mathrm{mg}, \mathrm{T} 15 \mathrm{mg}\end{array}$ & 7 & $\mathrm{He}$ & $\mathrm{R}=4.3 \mathrm{Me}$ & IGF-1 + FGF + Fibroblasts \\
\hline $3 \mathrm{~b}$ & M & 33 & $\mathrm{~T} 5 \mathrm{mg}$ & 7 & Ho & $\mathrm{L}=5.7 \mathrm{H}$ & c-erbB-2 + Neutrophils IGF-1 + FGF + Fibroblasts \\
\hline $4 \mathrm{a}$ & M & 53 & $\mathrm{~N}$ & 10 & $\mathrm{He}$ & $\mathrm{D}=11.0 \mathrm{Me} / \mathrm{L}$ & c-erbB-2 + Neutrophils EGF + Neutrophils \\
\hline $4 \mathrm{~b}$ & M & 53 & $\operatorname{Pr} 40 \mathrm{mg}$ & 10 & $E$ & $\mathrm{~L}=11.1 \mathrm{Me} / \mathrm{L}$ & Negative \\
\hline 5 & $\mathrm{~F}$ & 28 & $\mathrm{~N}$ & 2 & $E$ & $\mathrm{~L}=5.8 \mathrm{M}$ & Negative \\
\hline 6 & M & 21 & $\mathrm{Pl} 40 \mathrm{mg}, \mathrm{T} 5 \mathrm{mg}$ & 5 & $E$ & $\mathrm{R}=6.2 \mathrm{Me}$ & IGF-1 + FGF + Fibroblasts \\
\hline 7 & M & 42 & D $50 \mathrm{mg}$ & 7 & $E$ & $\mathrm{R}=5.1 \mathrm{Me}$ & IGF-1 + VEGF + Vessels \\
\hline 8 & $\mathrm{~F}$ & 42 & $\mathrm{~N}$ & 1 & $E$ & $\mathrm{R}=6.6 \mathrm{Me} / \mathrm{L}$ & Negative \\
\hline 9 & M & 27 & $\mathrm{~N}$ & 1 & $E$ & $\mathrm{R}=5.5 \mathrm{Me} / \mathrm{L}$ & Negative \\
\hline 10 & $\mathrm{~F}$ & 32 & $\mathrm{~N}$ & 2 & $\mathrm{E}$ & $\mathrm{L}=5.7 \mathrm{Me}$ & Negative \\
\hline 11 & $\mathrm{~F}$ & 28 & $\mathrm{Pl} 40 \mathrm{mg}$, T $10 \mathrm{mg}$ & 2 & $\mathrm{He}$ & $\mathrm{L}=5.6 \mathrm{Me} / \mathrm{H}$ & c-erbB-2 + Neutrophils EGF + Neutrophils \\
\hline 12 & $\mathrm{~F}$ & 32 & $\mathrm{~T} 5 \mathrm{mg}$ & 5 & $\mathrm{He}$ & $\mathrm{R}=5.0 \mathrm{Me}$ & IGF-1 + FGF + Fibroblasts VEGF + Vessels \\
\hline 13 & M & 33 & LTS $150 \mu \mathrm{g}$ & 2 & $E$ & $\mathrm{~L}=5.3 \mathrm{Me}$ & IGF-1 + \\
\hline 14 & $\mathrm{~F}$ & 26 & $\begin{array}{c}\text { LTS } 100 \mu \mathrm{g} \\
\text { (send to radiotherapy) }\end{array}$ & 6 & $E$ & $\mathrm{R}=6.8 \mathrm{H}$ & Negative \\
\hline 15 & $\mathrm{~F}$ & 35 & $\mathrm{~N}$ & 3 & $\mathrm{He}$ & $\mathrm{R}=7.5 \mathrm{~L}$ & Negative \\
\hline 16 & $\mathrm{~F}$ & 35 & $\mathrm{~N}$ & 3 & $E$ & $\mathrm{R}=6.4 \mathrm{~L}$ & PDGF-A + Amorphous substance \\
\hline 17 & $\mathrm{~F}$ & 30 & $\operatorname{Pr} 40 \mathrm{mg}$ & 1 & E & $\mathrm{R}=4.4 \mathrm{Me} / \mathrm{H}$ & Negative \\
\hline 18 & M & 23 & $\begin{array}{c}\mathrm{T} 40 \mathrm{mg} \\
\text { Post radiotherapy }\end{array}$ & 3 & $E$ & $\mathrm{R}=3.3 \mathrm{H}$ & Negative \\
\hline 19 & $\mathrm{~F}$ & 40 & $\mathrm{~T} 10 \mathrm{mg}, \mathrm{Pl} 40 \mathrm{mg}$ & 1 & $\mathrm{He}$ & $\mathrm{L}=6.8 \mathrm{Me}$ & Negative \\
\hline 20 & $\mathrm{~F}$ & 48 & $\mathrm{~N}$ & 1 & $E$ & $\mathrm{R}=4.1 \mathrm{Me}$ & PDGF-A + Amorphous substance \\
\hline 21 & M & 45 & C $1 \mathrm{mg}$ & 6 & $E$ & $\mathrm{~L}=5.4 \mathrm{Me}$ & IGF-1 + \\
\hline 22 & $M$ & 34 & Pt 60 mg, Pl 80 mg & 6 & $E$ & $\mathrm{~L}=5.5 \mathrm{Me}$ & FGF + Fibroblasts \\
\hline
\end{tabular}

\begin{tabular}{|lccc|}
\hline \multicolumn{4}{|c|}{ Table 2. Number of samples and IGF-1, FGF and VEGF expression } \\
& IGF-1 & FGF & VEGF \\
Positive & 7 & 5 & 2 \\
Negative & 17 & 19 & 22 \\
Total & 24 & 24 & 24 \\
\hline
\end{tabular}

apparent $^{(12)}$. Related to distribution of affected eye muscles, there are many controversies.

There was a paper showing that the muscles were not equally involved (e.g. the medial and the inferior being more frequently enlarged than the superior and lateral recti ${ }^{(13)}$. Conversely, no difference was found on A-scan (e.g., the medial, lateral, and superior recti all had an abnormal reflectivity in approximately $50 \%$ of patients ${ }^{(10)}$. In addition, the muscles appearing normal on CT scan had an abnormal reflectivity in the A-mode. These findings are in agreement with a previous report $^{(9)}$ and suggest that there is an even distribution of involvement among all the muscles, in accordance with an other report ${ }^{(14)}$. This is a critical point if any conclusion of our paper, i.e., the muscle on which we performed the biopsy was not necessarily involved in an inflammatory process at that time, even if an ultrasound reflectivity was abnormal. As there appears to be no difference between inflammatory patterns in any of the extraocular muscles, we chose for this reason to perform a biopsy of the lateral recti muscle because of easier surgical exposure.

The patients in our study had a variety of stages of CAS scores (Table 1) when the biopsy was performed, but the patients also presented different stages of their disease, and some patients may had more disease activity earlier. Five patients had ongoing steroid medication, and three had radiotherapy, which may have diminished the inflammatory response. Furthermore, the inflammatory process may be localized and not equally distributed throughout the muscle ${ }^{(14)}$. Thus, the biopsies might not be representative for the whole muscle.

A smaller percentage of patients with Graves's disease had both Graves's ophthalmopathy and pretibial dermopathy. We found only 2 patients with pretibial dermopathy, and both showed IGF-1 and FGF and CAS greater than 5. Patients displaying one or more of these extrathyroidal manifestations frequently develop severe Graves' ophthalmopathy ${ }^{(15)}$. It is possible that an expression of IGF-1 and FGF predispose to a worse outcome of Graves' ophthalmopathy.

A great variety of tissues are capable of producing their own IGF-1, suggesting in this way, that IGF-1 might be able to 
IGF-1 in Women



\section{IGF-1 in Men}



Patient Id

Graph 1 - Comparison between IGF-1 expression in male and female patients

act at the autocrine and paracrine level. High circulating levels of this hormone indicate some endocrine role ${ }^{(16)}$.

There is a paper ${ }^{(17)}$ that demonstrated that $\operatorname{IgG}$ prepared from patients with Graves' disease with or without overt ophthalmopathy interact with IGF-1 binding sites on orbital fibroblasts.

There was an ${ }^{(18)}$ analysis of glycosaminoglycans synthesized by retroocular fibroblasts in culture derived from an individual not suffering from thyroid disease and from three patients with Graves' ophthalmopathy. The effects of IGF-1 and PDGF on hyaluronan and proteoglycan synthesis were studied separately and in combination. In our study we found IGF-1 expression in seven cases, and in two cases, PDGF-A in a very non-specific presentation in amorphous material. Our results might imply a more relevant role for IGF-1 when compared with PDGF.

It was ${ }^{(5)}$ found that IGF-I may be a determinant of thyroid cell growth, both normal and in certain thyroid diseases including Graves' disease, and may be important in abnormal stimulation of retroocular connective tissue in Graves' as well.

FGF induces a proliferative response in mesodermal and neuroectodermal cells. This induction may create angiogenesis, healing and neural regeneration in vivo. Of these, one of the most important, angiogenesis, is directly related to the intensity and speed of recovery ${ }^{(19)}$.

There were studies on the role of FGF in the pathogenesis of nodular goiter. Thyroid epithelial cells are known to produce several growth factors and cytokines, which influence thyroid cell growth and function in an autocrine and/or paracrine manner ${ }^{(20)}$. It is already known that IGF-1 is overexpressed in toxic adenomas whereas EGF is found predominantly in thyroid neo- plasia. Most bFGF immunostaining was found in the connective tissue of all thyroid tissues with predominance in adenomas and Graves' diseases. In our study we found a positive expression of IGF-1 in 7 cases, more related with non-neoplastic growth, i.e. Graves' ophthalmopathy, and no expression of EGF, which seems related more with tumor processes.

Conversely, it was found that bFGF is synthesized in the neoplastic follicular cells of the thyroid, and aFGF and bFGF may have important roles in the neoplastic proliferation of follicular cells ${ }^{(21)}$.

There were other authors who found that TSH stimulates an increase in thyroid EGF receptors by increasing intracellular $\mathrm{CAMP}^{(22)}$.

VEGF can induce angiogenesis in a complex way, which involves selective division of endothelial cells, vascular membrane degradation surrounded by cellular matrix and migration of endothelial cells ${ }^{(23)}$.

Basically, VEGF increases vascular permeability and this became evident minutes after injection ${ }^{(24-25)}$.

This could be a reason that our patient number seven, who was being treated with diclofenac sodium, in spite of this still expressed VEGF, and still had CAS 7.

A significant increase in serum VEGF levels was reported in patients with untreated Graves' disease and goiter Hashimoto's thyroiditis compared with those in healthy subjects ${ }^{(26)}$. Serum VEGF levels in untreated patients with subacute thyroiditis were significantly higher than those in patients with untreated Graves' disease or Hashimoto's thyroiditis. In our study, one of these patients presented with a hyperthyroidism when biopsied, and the other with euthyroidism and VEGF was expressed in both biopsies. Clinically both had scores higher than CAS 5. 
There were suggestions that Placenta Growth Factor (PIGF) and vascular endothelial growth factor (VEGF), released by thyrocytes in response to the chronic activation of the TSH receptor pathway, may act through a paracrine mechanism on thyroid endothelium ${ }^{(27)}$.

The higher levels of VEGF expression in differentiated thyroid cancers of follicular cell origin were reported suggesting a role in oncogenesis ${ }^{(28)}$.

However, VEGF is also expressed in normal tissues such as kidney, lungs, heart which do not show evidence of angiogenesis ${ }^{(29-30)}$.

Another important stimulus for VEGF expression is a limitation in oxygen supply. Lower cellular $\mathrm{pH}$ and a higher concentration of lactate could induce the release of angiogenic peptides from macrophages and tumor cells ${ }^{(23)}$. It is well known that in Graves' ophthalmopathy, the restricted orbital compartment is associated with compression of orbital tissue and slow venous return. This may result in a limitation in the oxygen supply, lower $\mathrm{pH}$, and a higher concentration of lactate which could stimulate the VEGF expression, independent of other mechanisms such as inflammation.

\section{CONCLUSION}

In our study, all patients, but one, with positive expression of FGF, IGF-1 and VEGF, showed CAS greater than 5 (Graph 2). This suggests an important role of these growth factors in the pathogenesis and severity of Graves' opthalmopathy. As in previous reports, we found an inflammatory process in connective tissue and not in muscle fibres. The immunoexpression was found in neutrophils and amorphous substance in non-specific reactions. Fibroblasts and endothelial cells had a strong immunoexpression of IGF-1. Fibroblasts had a strong immunoexpression of FGF, and endothelial cells had a strong immunoexpression of VEGF.

Neither low or low/medium ultrasound reflectivity showed IGF-1, FGF and VEGF expression.

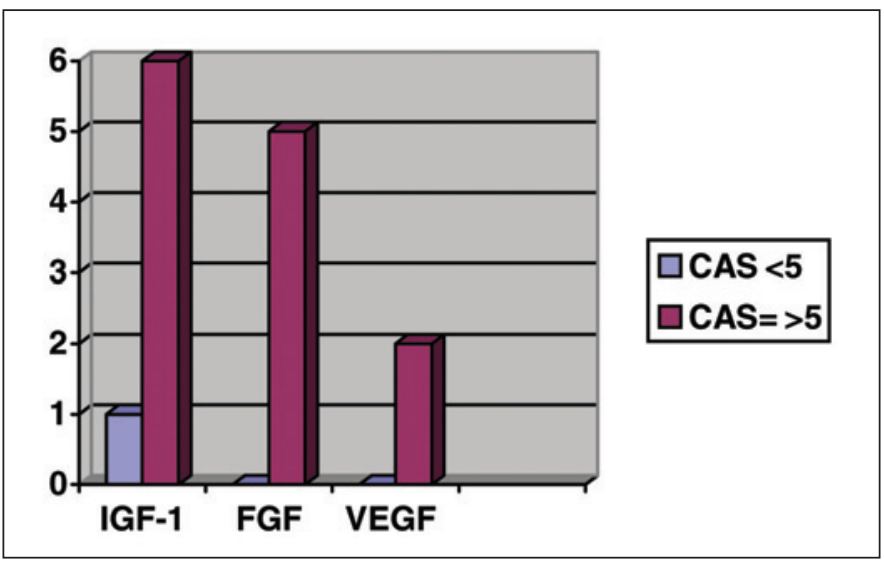

Graph 2 - Number of samples and IGF-1, FGF and VEGF expression in patients with CAS $<5$ and $\mathrm{CAS}=>5$
The endocrine status may not correlate directly with disease activity or even with immunoexpression of growth factors.

A better understanding of the pathogenesis of Graves' disease may allow the development of new preventive and therapeutic strategies to ameliorate the quality of life of Graves' disease patients.

\section{ACKNOWLEDGEMENTS}

Work supported by Grant from FAPESP (Fundacão de Pesquisa do Estado de S. Paulo, Brazil) to Vânia Nosé. We are in debt with Celia Nakanami, MD, for strabismus samples; Catey Bunce MSc, Medical Statistician, Moorfields Eye Hospital, UK, for her valuable statistical analysis; Leonor Cristina Manoja Roman, BS from Federal University of São Paulo; and Gustavo Victor, MD from Faculty of Medicine of Ribeirão Preto, São Paulo Univerity, Brazil, for technical support.

\section{RESUMO}

Objetivo: Investigar a expressão imuno-histoquímica de IGF-1, EGFr, EGF, c-erbB-2/HER-2/neu, PDGF-A, PDGF-B, FGF e VEGF na oftalmopatia de Graves. Métodos: Vinte e dois pacientes (oftalmopatia de Graves) foram submetidos à biópsia do músculo reto lateral e tecido fibroso e adiposo adjacente. O grupo controle foi de pacientes de cirurgia de estrabismo. Foi feita correlação entre achados clínico-oftalmológicos, endocrinológicos, ultra-sonográficos e da expressão imuno-histoquímica dos fatores de crescimento. Resultados: IGF-1: Houve 7 casos positivos (29,2\%). Houve correlação direta com o CAS (clinical activity score) elevado em todos os casos e em que consideramos CAS apenas acima de 5, em 54,5\%. FGF: Houve expressão em 5 casos $(20,8 \%)$ com relação direta com CAS elevado em todos os casos e em que consideramos CAS maior que $5(45,4 \%)$. VEGF: Houve dois casos positivos $(8,3 \%)$ para VEGF nas células endoteliais e estes casos também apresentavam CAS maior que 5. A imunorreatividade foi negativa em todo grupo controle. Conclusão: Todos os pacientes, com exceção de um, com expressão positiva para FGF, IGF-1 e VEGF mostraram CAS maior que 5, sugerindo importante papel destes fatores de crescimento na patogênese e gravidade da oftalmopatia de Graves. Entretanto, a análise estatística demonstrou associação significativa entre IGF-1 e o sexo masculino $(\mathrm{P}=0,034)$. Baixa refletividade ao ultra-som e condição endócrina não estiveram correlacionadas.

Descritores: Imuno-histoquímica; Receptor erbB-2/análise; Fator de crescimento insulin-like I/análise; Receptor do fator de crescimento epidérmico/análise; Fator de crescimento epidérmico/análise; Receptor tipo alfa para fator de crescimento derivado de plaqueta/análise; Proteínas proto-oncogênicas c-sis/análise; Fatores de crescimento de fibroblastos/análise; Fator A de crescimento do endotélio vascular/análise; Oftalmopatia de Graves/metabolism 


\section{REFERENCES}

1. Matos K, Nosé V, Manso PG, Ho RF, Marback E, Nakanami C, et al. Correlation Between Clinical and Histological Analyses in Retroocular Connective Tissues and Extraocular Muscles from Patients with Graves' Opthalmopathy. Endocr Pathol. 2000;11(2):185-94

2. Heufelder AE. [Pathogenesis of Graves' ophthalmopathy]. Z Arztl Fortbild Qualitatssich. 1999;93(Suppl 1):35-9. Review. German.

3. Binoux M, Hossenlopp P, Lassacre C, Hardouin N. Production of insulin-like growth factors and their carrier by rat pituitary gland and brain explants in culture. FEBS Lett. 1981;124(2):178-84.

4. Baxter RC. The somatomedins: insulin-like growth factors. Adv Clin Chem. 1986;25:49115. Review.

5. Tramontano D, Cushing GW, Moses AC, Ingbar SH. Insulin-like growth factor-I stimulates the growth of rat thyroid cells in culture and synergizes the stimulation of DNA synthesis induced by TSH and Graves'-IgG. Endocrinology. 1986;119(2):940-2.

6. Mourits MP, Prummel MF, Wiersinga WM, Koornneef L. Clinical activity score as a guide in the management of patients with Graves' ophthalmopathy. Clin Endocrinol (Oxf). 1997;47(1):9-14. Erratum in: Clin Endocrinol (Oxf). 1997;47(5):632. Comment in: Clin Endocrinol (Oxf). 1997;47(1):15.

7. Werner SC. Modification of the classification of the eye changes of Graves' disease: recommendations of the Ad Hoc Committee of the American Thyroid Association. J Clin Endocrinol Metab. 1977;44(1):203-4.

8. Bartley GB, Gorman CA. Diagnostic criteria for Graves' ophthalmopathy. Am J Ophthalmol. 1995;119(6):792-5. Review.

9. Skalka HW. The use of ultrasonography in the diagnosis of endocrine orbitopathy. Neuroophthalmology. 1980;1:109-16.

10. Prummel MF, Suttorp-Schulten MS, Wiersinga WM, Verbeek AM, Mourits MP, Koornneef L. A new ultrasonographic method to detect disease activity and predict response to immunosuppressive treatment in Graves ophthalmopathy. Ophthalmology. 1993;100(4):556-61. Comment in: Ophthalmology. 1993;100(10):1430-1.

11. Byrne SF, Gendron EK, Glaser JS, Feuer W, Atta H. Diameter of normal extraocular recti muscles with echography. Am J Ophthalmol. 1991;112(6):706-13.

12. Weetman AP. Thyroid-associated eye disease: pathophysiology. Lancet. 1991;338(8758):25-8. Comment in: Lancet. 1991;338(8764):454-5.

13. Marcocci C, Vitti P, Cetani F, Catalano F, Concetti R, Pinchera A. Thyroid ultrasonography helps to identify patients with diffuse lymphocytic thyroiditis who are prone to develop hypothyroidism. J Clin Endocrinol Metab. 1991; 72(1):209-13.

14. Hufnagel TJ, Hickey WF, Cobbs WH, Jakobiec FA, Iwamoto T, Eagle RC. Immunohistochemical and ultrastructural studies on the exenterated orbital tissues of a patient with Graves' disease. Ophthalmology. 1984;91(11):1411-9.

15. Heufelder AE. Pathogenesis of Graves' ophthalmopathy: recent controversies and progress. Eur J Endocrinol. 1995;132(5):532-41.

16. Scott CD, Martin JL, Baxter RC. Rat hepatocyte insulin-like growth factor I and binding protein: effect of growth hormone in vitro and in vivo. Endocrinology 1985;116(3):1102-7.

17. Weightman DR, Perros P, Sherif IH, Kendall-Taylor P. Autoantibodies to IGF-1 binding sites in thyroid associated ophthalmopathy. Autoimmunity. 1993; 16(4):251-7.

18. Imai Y, Odajima R, Inoue Y, Shishiba Y. Effect of growth factors on hyaluronan and proteoglycan synthesis by retroocular tissue fibroblasts of Graves' ophthalmopathy in culture. Acta Endocrinol (Copenh). 1992;126(6):541-52.

19. Cuevas E, Giménez-Gallego G, Carceller F, Cuevas B, Crespo A. Single topical application of human recombinant basic fibroblast growth factor (rbFGF) promotes neovascularization in rat cerebral cortex. Surg Neurol. 1993;39(5):380-4.

20. Gärtner R, Veitenhansl M, Aktas J, Schopohl D. Role of basic fibroblast growth factor in the pathogenesis of nodular goiter. Exp Clin Endocrinol Diabetes. 1996;104(Suppl 4):36-8.

21. Kodama M, Daa T, Kashima K, Yokoyama S, Nakayama I, Noguchi S. Immunohistochemical localization of acidic and basic fibroblast growth factors in human benign and malignant thyroid lesions. Jpn J Clin Oncol. 1994;24(2):66-73.

22. Duh QY, Siperstein AE, Miller RA, Sancho JJ, Demeure MJ, Clark OH. Epidermal growth factor receptors and adenylate cyclase activity in human thyroid tissues. World J Surg. 1990;14(3):410-7; discussion 418.

23. Folkman J, Shing Y. Angiogenesis. J Biol Chem. 1992;267(16):10931-4.

24. Senger DR, Galli SJ, Dvorak AM, Perruzzi CA, Harvey VS, Dvorak HF. Tumor cells secrete a vascular permeability factor that promotes accumulation of ascites fluid. Science. 1983;219(4587):983-5.

25. Kraft A, Weindel K, Ochs A, Marth C, Zmija J, Schumacher P, et al. Vascular endothelial growth factor in the sera and effusions of patients with malignant and nonmalignant disease. Cancer. 1999;85(1):178-87.

26. Iitaka M, Miura S, Yamanaka K, Kawasaki S, Kitahama S, Kawakami Y, et al. Increased serum vascular endothelial growth factor levels and intrathyroidal vascular area in patients with Graves' disease and Hashimoto's thyroiditis. J Clin Endocrinol Metab. 1998;83(11):3908-12.

27. Viglietto G, Romano A, Manzo G, Chiappetta G, Paoletti I, Califano D, et al. Upregulation of the angiogenic factors PlGF, VEGF and their receptors (Flt-1, Flk$1 / \mathrm{KDR}$ ) by TSH in cultured thyrocytes and in the thyroid gland of thiouracil-fed rats suggest a TSH-dependent paracrine mechanism for goiter hypervascularization. Oncogene. 1997;15(22):2687-98.

28. Soh EY, Duh QY, Sobhi SA, Young DM, Epstein HD, Wong MG, et al. Vascular endothelial growth factor expression is higher in differentiated thyroid cancer than in normal or benign thyroid. J Clin Endocrinol Metab. 1997; 82(11):3741-7.

29. Shweiki D, Itin A, Neufeld G, Gitay-Goren H, Keshet E. Patterns of expression of vascular endothelial growth factor (VEGF) and VEGF receptors in mice suggest a role in hormonally regulated angiogenesis. J Clin Invest. 1993;91(5):2235-43.

30. Berse B, Brown LF, Van Dde Water L, Dvorak HF, Senger DR. Vascular permeability factor (vascular endothelial growth factor) gene is expressed differentially in normal tissues, macrophages, and tumors. Mol Biol Cell. 1992; $3(2): 211-20$. 